\title{
Water Quality and Socio-economic Studies of the Pumdi Environment of Keibul Lamjao National Park, Loktak Lake, Manipur, India
}

\author{
Maibam Haripriya Devi ${ }^{1}$, Potsangbam Kumar Singh ${ }^{2, *}$, Manabendra Dutta Choudhury ${ }^{3}$ \\ ${ }^{1}$ Department of Botany, Manipur College, Imphal, Manipur, India \\ ${ }^{2}$ Department of Life Sciences, Manipur University, Manipur, India \\ ${ }^{3}$ Department of Life Science and Bioinformatics, Assam University Silchar, Silchar, India
}

\section{Email address:}

haripriyamaibam@gmail.com (M. H. Devi), potsangbamk031@gmail.com (P. K. Singh),drmdc@bioinfoaus.ac.in (M. D. Choudhury)

\section{To cite this article:}

Maibam Haripriya Devi, Potsangbam Kumar Singh, Manabendra Dutta Choudhury. Water Quality and Socio-economic Studies of the Pumdi Environment of Keibul Lamjao National Park, Loktak Lake, Manipur, India. Frontiers in Environmental Microbiology.

Vol. 1, No. 1, 2015, pp. 1-8. doi: 10.11648/j.fem.20150101.11

\begin{abstract}
Loktak Lake is the largest fresh water Lake in the North-eastern India. Keibul Lamjao National Park (KLNP) is a floating-mat (Phumdi) park inside the Lake. Study deals with the inter-related approaches: micobiological study, free-listing, participant observation and preference ranking of the six study sites of KLNP. Generally, plant collection per day was about $600 \mathrm{~kg}$ of Hedychium coronarium J. Koenig which were extracted from the park and found to be the most preferable species; while Persicaria sagittata (L.) H. Gross, as the least among the selected plants. Microbiological analysis of water for the six study sites recorded high pollution as evidenced by high values of Standard Plate Count (SPC) for bacteria ranging from 73,500-96,500 and microbial analysis of MPN (Most Probable Number) of coliform bacteria varies between100 and 320/100 $\mathrm{ml}$ and faecal coliform 95 and 200/100 ml. Free $\mathrm{CO}_{2}$ concentrations varied at the surface from 2-60 mg/l and 6-70 mg/1 at the bottom of the park. In the KLNP environment the higher $\mathrm{CO}_{2}$ and lower concentrations of dissolved oxygen (DO) might be due to the floating mat (Phumdi) nature, in which light and exchange of gases does not occur as it does in the natural water bodies.
\end{abstract}

Keywords: Loktak Lake, Keibul Lamjao National Park, Phumdi (Floating-mat), Water quality, Socio-economic studies, Microbiological Analysis, Bioresource Utilization and Conservation

\section{Introduction}

Wetlands are vital ecosystems which provide livelihoods for the millions of people who live with in and around them. These wetland environments are legally owned by the indigenous communities [1]. Yet the indigenous peoples have been more frequently evicted from protected areas [2]. The plants of wetland ecosystems played fascinating roles in the life of human beings since time immemorial as food, fodder and medicine. A reduced population and lack of macrophytes in a lake indicate a change of the aquatic environment [3].

Conflicts between authorities and indigenous population over resource sharing has been observed and reported for decades [4]. Reasons for these conflicts can be interpreted from different perspectives such as infringement of agricultural rights, fishing, aquaculture, etc. Utilization of wild edible plants (WEPs) as food supplements is a global phenomenon and has been reported from many countries [5,
6]. Plant collection pattern is associated with the perception and relative importance of useful plants which depend on cultural factors [7].

Among the wetlands, Loktak Lake is a fresh water wetland of Manipur State, North-eastern India and Keibul Lamjao National Park (KLNP) is a natural and floating park made up of phumdis inside the lake engaged for conservation of endangered Sangai (Rucervus eldii eldii McClelland). At present, this park is one of the remaining natural habitats of this endangered deer [8,9]. KLNP, which was first declared as a wildlife sanctuary in 1954, is now officially under the IUCN Category-II of National Parks [10].

Phumdis are heterogeneous mass of soil, vegetation and organic matters in different degrees of decay; it is very rich in plant diversity. Singh and Singh [11] reported about 48 species distributed in the park. Some floating plants are the primary plants involved in the formation of the phumdi. Some of the major grass species associated with the phumdi was for the first time reported by Gee [12] from KLNP viz., 
Alpinia nigra, Phragmites karka, Saccharum arundinaceum, S. bengalens, S. procerum, Zizania latifolia and other miscellaneous plants. These plants are very useful as food (Wild edible), fuel, medicine, fodder fencing and also for many other purposes.

Loktak Hydroelectric Power Project has direct effect, on the natural cycle of phumdi and leading to the deterioration phumdi. Before the installation of the Loktak project, the floating mat phumdi settle itself at the bottom of the lake and the roots of the macrophytes are recharged by absorbing nutrients from the bottom of the lake. The invasion of the park by the aquatic weed called Paragrass [Brachiaria mutica (Forssk.) Stapf], which is spreading unchecked and may become a threat to the natural habitat in near future. Biotic interactions in the form of competition are a common phenomenon among the exotic and native species [13].
However, among the species, co-existence is favoured instead of competition [14]. The present study focuses on the anthropogenic pressure on the KLNP from the indigenous population and suggesting mitigating solutions for sustainable conservation.

\section{Materials and Methods}

Several field works were undertaken at the 6 study sites (viz., Keibul, Nongmaikhong, Sargam, Kumbi, Khordak and Komlakhong) near the vicinity of the park (Fig.1) during March, 2010 to December, 2013. The plants found in the sites were processed to herbarium specimens. A combined methodology was followed so as to cover the complex pattern of plant collection among the indigenous people.

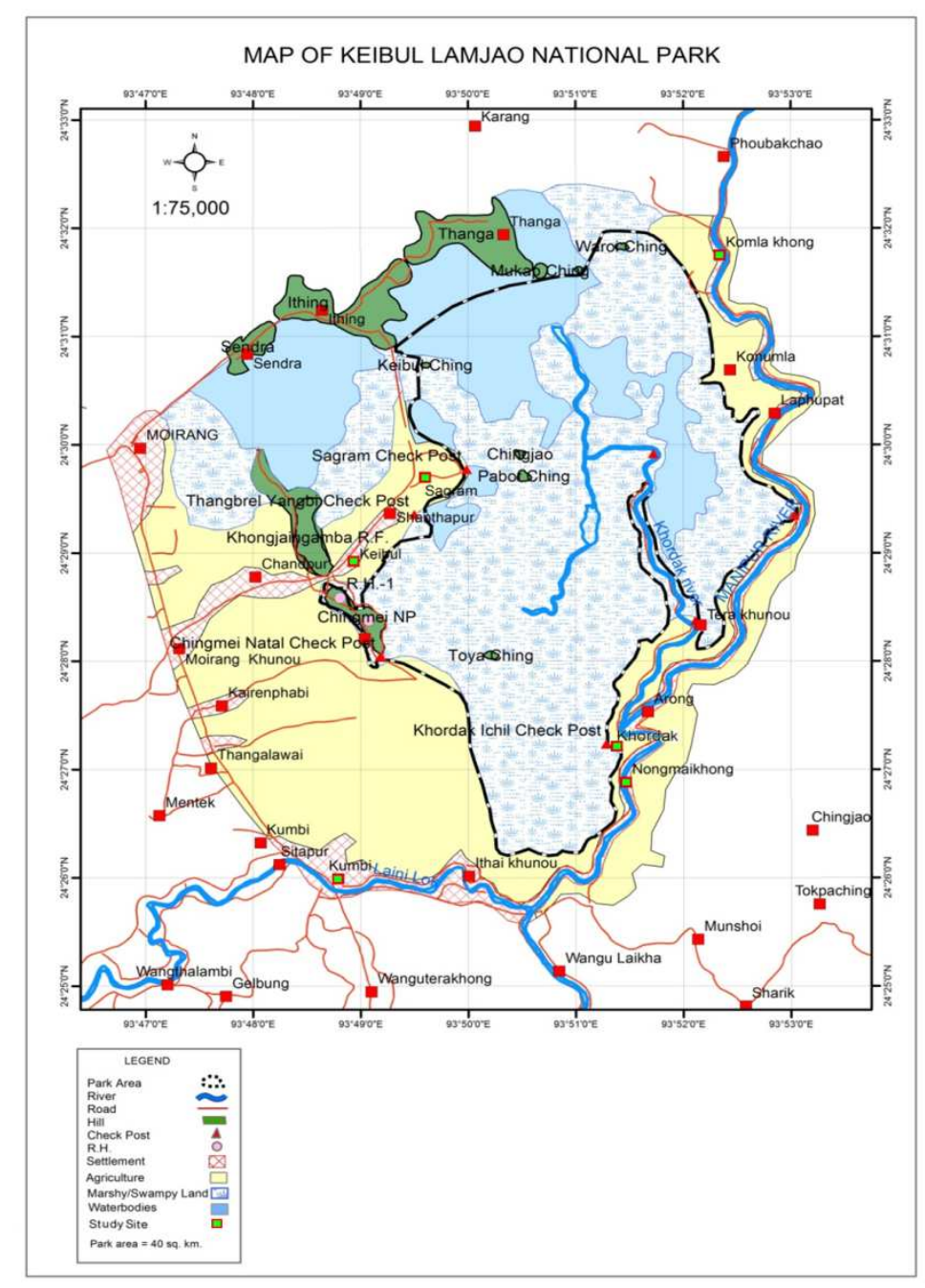

Fig. 1. Map of Keibul Lamjao National Park (KLNP), Loktak Lake, Manipur, showing the six study sites viz., 1)Keibul, 2)Nongmaikhong, 3)Sargam, 4)Kumbi, 5)Khordak and 6)Komlakhong.

\subsection{Description of the Study Site}

The KLNP is the only floating National park (phumdi) in the globe. KNLP is located in the southeastern corner of Loktak Lake $\left(287 \mathrm{~km}^{2}\right.$ in area) a fresh water lake of Manipur which is one of the 25 Ramsar sites of international importance in India. The park covers an area of about $40 \mathrm{~km}^{2}$ and situated between $24^{0} 27^{\prime} \mathrm{N}$ to $24^{0} 31^{\prime} \mathrm{N}$ latitude and $93^{0} 53^{\prime} \mathrm{E}$ to $93^{0} 55^{\prime} \mathrm{E}$ longitudes having two distinct geographical zones. In zone-i, the phumdi area is about 29 $\mathrm{km}^{2}$, which is constituted by the combination of soil, vegetation and organic matter in different stages of decay 
forms the major area and the zone-ii, is a Water body area ( 9 $\mathrm{km}^{2}$ ) around the floating portion. The local population residing in the six study villages surrounding the park were selected as informants and gender profile of the informants were also recorded for the present research work (Table 1).

Table 1. Gender profile of the informants

\begin{tabular}{lllll}
\hline SINo. & Location & Male & Female & Total \\
\hline 1 & Keibul & 8 & 11 & 19 \\
2 & Nongmaikhong & 3 & 4 & 7 \\
3 & Sargam & 7 & 3 & 10 \\
4 & Kumbi & 2 & 7 & 9 \\
5 & Khordak & 5 & 2 & 7 \\
6 & Komlakhong & 6 & 3 & 9 \\
\hline
\end{tabular}

\subsection{Ethnographic Profile of the Informants}

Informationwerecollectedbothfromthepeoplecollectingplan tsfromKLNPandforestsecurityguardsofthepark.Geographicdis tributionsofthesixstudysitesareprovided(Fig.1).Demographicp rofileofthelocationsitesexhibitsimilarfeaturesinsocioeconomic conditions (Table 2). Information was collected from plant collectors inhabiting in these villagers, while some information was also collected from security guards of the park. All the informants belong to Meitei and Meitei Pangal (Manipuri Muslim) communities, who are borne and brought up in these areas. Prior informed consents were also taken from respective informants.

Table 2. Demographic profile of the six study sites of Keibul Lamjao National Park (KLNP)

\begin{tabular}{|c|c|c|c|c|c|c|}
\hline $\begin{array}{l}\text { Charact- } \\
\text { eristics }\end{array}$ & Site-I:Keibul & $\begin{array}{l}\text { Site- } \\
\text { II:Nongmaikhong }\end{array}$ & Site-III:Sagram & Site-IV:Kumbi & Site-V:Khordak & $\begin{array}{l}\text { Site- } \\
\text { VI:Komlakhong }\end{array}$ \\
\hline Longitude & $093^{0} 48^{/ 52.7^{/ /} \mathrm{E}}$ & $093^{0} 51^{\prime} 07.1^{/ /} \mathrm{E}$ & $093^{0} 4953.7^{/ /} \mathrm{E}$ & $093^{0} 50^{\prime} 13.2^{/ /} \mathrm{E}$ & $093^{0} 51^{\prime} 20.8^{/ /} \mathrm{E}$ & $093^{0} 52 / 20.55^{/ /} \mathrm{E}$ \\
\hline Latitude & $24^{0} 28^{\prime} 44.6^{1 /} \mathrm{N}$ & $24^{0} 27^{\prime} 05.7^{/ /} \mathrm{N}$ & $24^{0} 29^{\prime} 50.4^{\prime /} \mathrm{N}$ & $24^{0} 26^{\prime} 44.2^{1 /} \mathrm{N}$ & $24^{0} 2923.4^{/ /} \mathrm{N}$ & $24^{0} 31^{\prime} 44.77^{/ /} \mathrm{N}$ \\
\hline Altitude & $772 \mathrm{~m}$ & $772 \mathrm{~m}$ & $772 \mathrm{~m}$ & $780 \mathrm{~m}$ & $778 \mathrm{~m}$ & $778 \mathrm{~m}$. \\
\hline $\begin{array}{l}\text { Populatio } \\
\mathrm{n}(2011)\end{array}$ & 3100 & 990 & 848 & 399 & 832 & 3539 \\
\hline $\begin{array}{l}\text { Number } \\
\text { of } \\
\text { household }\end{array}$ & 610 & 210 & 158 & 85 & 162 & 598 \\
\hline $\begin{array}{l}\text { Averagen } \\
\text { oofperson } \\
\text { sperhouse }\end{array}$ & 5.08 & 4.7 & 5.3 & 4.7 & 5.13 & 5.9 \\
\hline $\begin{array}{l}\text { Major } \\
\text { Profession }\end{array}$ & $\begin{array}{l}\text { Fishing,PlantCollecti } \\
\text { on,Poultry,Piggery,F } \\
\text { arming,Business,Lab } \\
\text { ourer }\end{array}$ & $\begin{array}{l}\text { Fishing,PlantCollecti } \\
\text { on,Poultry,Piggery,F } \\
\text { arming,Business,Lab } \\
\text { ourer }\end{array}$ & $\begin{array}{l}\text { Fishing,PlantCollecti } \\
\text { on,Poultry,Piggery,F } \\
\text { arming,Business,Lab } \\
\text { ourer }\end{array}$ & $\begin{array}{l}\text { Fishing,PlantCollecti } \\
\text { on,Poultry,Piggery,F } \\
\text { arming,Business,Lab } \\
\text { ourer }\end{array}$ & $\begin{array}{l}\text { Fishing,PlantCollecti } \\
\text { on,Poultry,Piggery,F } \\
\text { arming,Business,Lab } \\
\text { ourer }\end{array}$ & $\begin{array}{l}\text { Fishing,PlantCollecti } \\
\text { on,Poultry,Piggery,F } \\
\text { arming,Business,Lab } \\
\text { ourer }\end{array}$ \\
\hline $\begin{array}{l}\text { House } \\
\text { Types }\end{array}$ & $\begin{array}{l}\text { Huts, semi-pacca, } \\
\text { Katcha }\end{array}$ & $\begin{array}{l}\text { Huts, semi-pacca, } \\
\text { Katcha }\end{array}$ & $\begin{array}{l}\text { Huts, semi-pacca, } \\
\text { Katcha }\end{array}$ & $\begin{array}{l}\text { Huts, Pacca, semi- } \\
\text { pacca, Katcha }\end{array}$ & $\begin{array}{l}\text { Huts, semi-pacca, } \\
\text { Katcha }\end{array}$ & $\begin{array}{l}\text { Huts, Pacca, semi- } \\
\text { pacca, Katcha }\end{array}$ \\
\hline $\begin{array}{l}\text { Literate } \\
\text { Population }\end{array}$ & 1910 & 640 & 558 & 359 & 595 & 2639 \\
\hline $\begin{array}{l}\text { Illiterate } \\
\text { Population }\end{array}$ & 1090 & 350 & 290 & 40 & 237 & 900 \\
\hline $\begin{array}{l}\text { Total } \\
\text { working } \\
\text { force }\end{array}$ & 2025 & 625 & 490 & 289 & 654 & 2987 \\
\hline $\begin{array}{l}\text { Main } \\
\text { worker }\end{array}$ & 1155 & 380 & 315 & 201 & 540 & 1877 \\
\hline $\begin{array}{l}\text { Main } \\
\text { cultivator }\end{array}$ & 1035 & 210 & 212 & 125 & 399 & 1478 \\
\hline $\begin{array}{l}\text { Main } \\
\text { agricultur } \\
\text { e } \\
\text { Main }\end{array}$ & 520 & 325 & 105 & 135 & 375 & 267 \\
\hline $\begin{array}{l}\text { house } \\
\text { hold } \\
\text { industry }\end{array}$ & 1034 & 395 & 175 & 87 & 277 & 755 \\
\hline $\begin{array}{l}\text { Main } \\
\text { other } \\
\text { worker }\end{array}$ & 845 & 275 & 140 & 136 & 207 & 287 \\
\hline $\begin{array}{l}\text { Not } \\
\text { cultivated } \\
\text { Workers }\end{array}$ & 205 & 112 & 107 & 97 & 117 & 755 \\
\hline $\begin{array}{l}\text { less than } 6 \\
\text { months }\end{array}$ & 1005 & 545 & 320 & 218 & 315 & 897 \\
\hline
\end{tabular}

\subsection{Free Listing of Useful Plants}

In the initial phase of data collection, free listing method was used to generate a comprehensive list of plant collected from the park. Free listing is an important method for the understanding of how a community defines their knowledge domain and also provides salient (meaningful) information about the different plant species used by the community [15]. 


\subsection{Preference Ranking}

In order to determine species preference among the local communities, a paired comparison of species was undertaken [16]. Ten mostly collected species were identified from free listing activities. Then, the respondents were asked to state their preference between any two species. Score is determined by the total number of mentions in the table and highest rank is assigned accordingly. An overall ranking was prepared by Kemeny-Young Method [17] with algorithm highlighted in Vote-Fair Ranking website [18] (http://www.votefair.org/calculation_details_popularity.html) using preferential ranks and pair-wise comparison.

\subsection{Specimen Collection and Identification}

Plant species mentioned by the traditional communities were collected from the field. Identification is done by referring to relevant state flora [19]. Plants were identified in the Department of Life Sciences, Manipur University, Canchipur, Imphal and Botanical Survey of India, Eastern Circle, Shillong. Voucher specimens were deposited at the herbarium of Department of Life Sciences, Manipur University. Plant names were cross checked with International Plant Name Index [20] (www.ipni.org) and Plant List websites [21] (www.theplantlist.org).

\subsection{Analysis of Water Quality}

Several microbiological analyses of water and water quality parameters were undertaken for the 6 study sites (viz., Keibul, Nongmaikhong, Sargam, Kumbi, Khordak and Komlakhong) of the KLNP during March, 2010 to December 2013. Standard plate count (SPC) for bacteria, MPN (Most Probable Number) of coliform bacteria and faecal coliforms were determined. Detail water quality analyses were carried out during the tenure of the research programme and the mean value of the triplicate observations were reported following the standard method of Jain et al. [22].

\section{Results and Discussion}

In the course of the study, ethno-botanical knowledge was collected from 61 informants. Those informants were randomly selected from the villagers of the six study sites and forest guards. Gender profile of the informants is represented in Table1. While all the informants collected plants from KNLP for various purposes, their main sources of livelihood varied, which is presented in Fig.2 \& Fig.3.

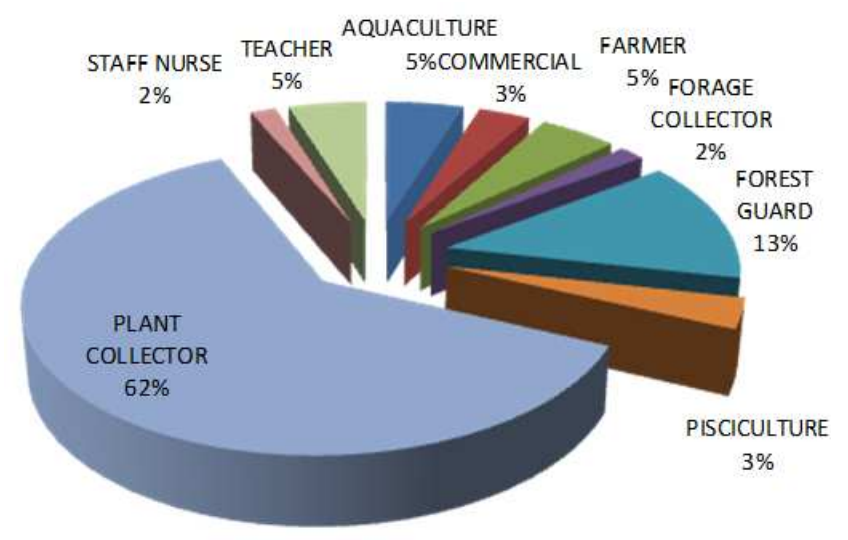

Fig. 2. Professions of the informants

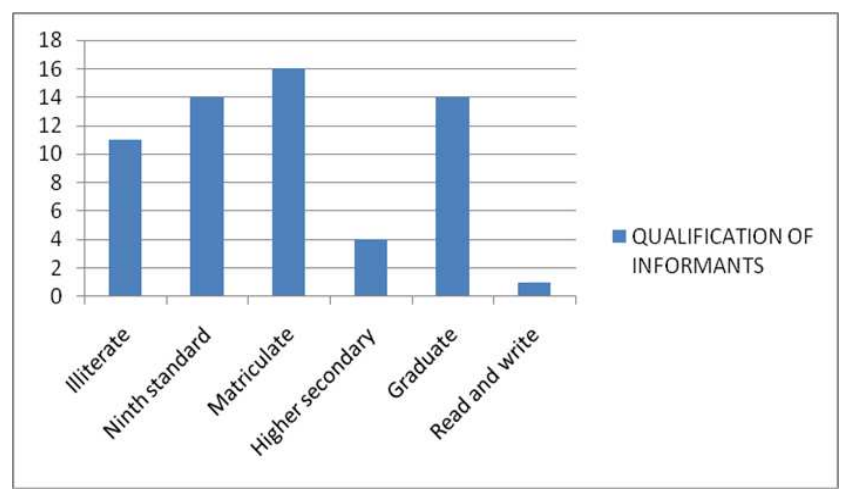

Fig. 3. Qualification of the informants

From the free listing activities, local people and forest guards identified 47 plants of ethno-botanical importance. These plants are collected by the local people whenever the need arises. Their collection area usually extends from 1 to 2 $\mathrm{km}$ into the park from the perimeter. Frequently cited species exhibit different preference among the local people.

Table 3. Preference ranking of 10 most popular plants at different localities

\begin{tabular}{llllllll}
\hline Species & Combined ranking & Keibul & Nongmai-khong & Sargam & Kumbi & Khor-dak & Komlakhong \\
\hline Hedychium coronarium J.Koenig & i & 1 & 4 & 1 & 2 & 1 & 2 \\
Alpinia nigra (Gaertn.)Burtt. & iii & 2 & 2 & 2 & 4 & 3 & 3 \\
Oenanthe javanica (Blume)DC. & iv & 3 & 3 & 3 & 3 & 2 & 5 \\
Persicaria barbata (L.)H.Hara & ii & 4 & 1 & 4 & 1 & 6 & 1 \\
Ipomoea aquatic Forssk. & v & 5 & 6 & 5 & 5 & 4 & 9 \\
Phragmites karka (Retz.)Trin.exSteud. & vi & 6 & 5 & 6 & 7 & 9 & 4 \\
Zizania latifolia (Griseb.)Turcz.ex Stapf. & viii & 9 & 7 & 7 & 8 & 7 & 6 \\
Hydrilla vercillata (L.f.)Royle & xi & 7 & 9 & 8 & 6 & 8 & 7 \\
Leersia hexandra SW. & vii & 8 & 8 & 9 & 9 & 5 & 8 \\
Persicaria sagittata (L.)H.Gross & x & 10 & 10 & 10 & 10 & 10 & 10 \\
\hline
\end{tabular}

The combined ranking of the ten selected plants depends upon the following factors: i) high market demand in the capital city Imphal, ii) widely used by the Manipuri community of the state and iii) availability throughout the park. The ten preferred plants can be categorized into three types based on their ethno-botanical importance viz., i) Food, 
ii) Aqua-culture and iii) Commercial and house hold activities. Combined ranking (CR) of the collected plants were tabulated (Table 3), Hedychium coronarium (Loklei) placed as the most preferable species, while Persicaria sagittata (Eeshing lilhar) as the least among the ten species.

From the conservation context threat to wild plants can be categorized into two types. The food plants like: Hedychium coronarium (CR-i), Alpinia nigra (CR-iii) and Zizania latifolia (CR-viii) are of potential threat type. In case of $H$. coronarium and $A$. nigra the plant collectors uprooted the rhizomes which are in different growth stages. However, with respect to $Z$. latifolia the tender aerial parts are collected during pre-flowering stage (Table 3 ). The degradation of the Wild Edible Plants (WEPs) from the nearby areas to the interior of the park is due to overharvesting by the indigenous population.

In case of food plants like Oenanthe javanica (CR-iv), Persicaria barbata (CR-ii), Ipomoea aquatica (CR-v) and $P$. sagittata (CR-x), though their collection preference is high except in $P$. sagittata, they are under less threat because the indigenous population prefers only the young tender shoots, so that there's enough time lapse for the new shoots to be regenerated (Table3).

The second category, Hydrilla verticillata is used for aquaculture. Among the six sites, Kumbi is the most preferred site for the plant collection. Although the plant has no direct affiliation with the Sangai deer, it indirectly supports the growth of the other plants. Local people use to collect it for fish food and also as traditional coolant for fresh fish.

The third category is plants collected for commercial and house hold uses e.g., Phragmites karka and Leersia hexandra. The indigenous population used Tou (P. karka) for different purposes. Preparation of bobbin (langchak) in weaving, as raw material for different types of mats which are locally known as phak and phaklong, fencing, fishing purposes, as frame work for mud walls, plant supporter for cultivated crops like pea and as one of the constituents to offer to the deities in socio-religious purposes, are some to mention. Moreover, the Muslim communities also harvest the plant as fire-woods which results in maximum collection. Muslim men folks usually collected Tou (more than100 bundles) and store them in their home plots.

Preference of the plant species varied with the locality. These variations reflect the local preference to different species. Alpinia, Hedychium, Ipomoea, Persicaria and Zizania species were commonly available in the KLNP and harvested for consumption and income generation [23]. Generally, plant harvesting is done by an individual person or a team of 3-4 women in a boat for duration of 7-8 hours in the park depending upon the plant type collected. Rarely a man may also be included in the team of three women collectors. Usually, harvesting starts from morning after breakfast at around $9.30 \mathrm{a} . \mathrm{m}$. and return back at around 5.30 to $6.00 \mathrm{p} . \mathrm{m}$. in the evening. Mainly the collected plants are sold as a means of generating income which amount from 300 to 400 INR per person per day.

Generally, majority of the informants were women folk belonging to 25 to 60 year aged group who are engaged in collecting ethno-botanically important plants from the park. It was observed that during the study period an average of 90 to 100 women and men folk were engaged in plant collection on a daily basis which comprises 10-15 from Khordak, 10-15 from Nongmaikhong, 15-20 from Kumbi, 10-15 from Sargam, 10-15 from Keibul and 20-25 from Komlakhong. Regarding harvesting volume, each person could collect 1 bag of Hedychium coronarium (about $10 \mathrm{~kg}$ capacity). In a day numbers of plant collectors in the six study sites were more than persons collecting 100 baskets or cement bags of about $10 \mathrm{~kg}$ of Loklei per bag. In a day a total of about 600 $\mathrm{kg}$ of Loklei were extracted from the KLNP (Table 4). Plant collection is also practiced by families having other sources of income, such as government service, business, farming etc. which is reflected in demographic profile in Table 2.

Table 4. Volume of Daily Plant Collection (Average) by the collectors from KLNP

\begin{tabular}{|c|c|c|c|c|c|c|}
\hline Scientific name & Team & Volume(Kg)/person & Rate(INR.) & No. of visit per week & Purpose & Availability \\
\hline Alpinia nigra & 3 persons & $\begin{array}{l}\text { Cement bag } \\
(20 \times 30 \text { inches })(10 \mathrm{~kg})\end{array}$ & INR.400/bag & Everyday & Market, food & Throughout the year \\
\hline $\begin{array}{l}\text { Hedychium } \\
\text { coronarium }\end{array}$ & 3 persons & $10 \mathrm{~kg}-20 \mathrm{~kg}$ & INR.400/bag & Everyday & Market, food & Throughout the year \\
\hline $\begin{array}{l}\text { Hydrilla } \\
\text { verticillata }\end{array}$ & One person & $\begin{array}{l}\text { 1boatful } \\
\text { (3x14feet) }\end{array}$ & Nil & Everyday & Fish & Throughout the year \\
\hline Ipomoea aquatica & 1person & 1(40x30inches) & INR.200/bag & Everyday & Market, food & Throughout the year \\
\hline Leersia hexandra & $\begin{array}{l}\text { Per boat- } \\
\text { one person }\end{array}$ & $\begin{array}{l}4-5 \\
\text { bundles } / 15 \mathrm{~kg} / \text { bundle }\end{array}$ & Nil & 2trip/day, everyday & $\begin{array}{l}\text { Fodder, fishery, } \\
\text { piggery }\end{array}$ & Throughout the year \\
\hline $\begin{array}{l}\text { Oenanthe } \\
\text { javanica }\end{array}$ & 1person & $\begin{array}{l}\text { 1 gunny bag } \\
\text { (30x43inches) }\end{array}$ & INR.200/bag & Everyday & Market, food & Throughout the year \\
\hline $\begin{array}{l}\text { Persicaria } \\
\text { barbata }\end{array}$ & 1person & 1basket(1kg) & $\begin{array}{l}\text { INR.90- } \\
100 / 500 \mathrm{~g}\end{array}$ & Everyday & Market, food & Frequently, March-April \\
\hline $\begin{array}{l}\text { Persicaria } \\
\text { sagittata }\end{array}$ & 1person & $2 \mathrm{~kg}$ & 10minute & Everyday & Market, Food & June-July \\
\hline Phragmites karka & 5-10team & 100-200bundles & $\begin{array}{l}\text { INR10 } \\
\text { minute/bundle }\end{array}$ & Everyday & $\begin{array}{l}\text { Household, } \\
\text { commercial }\end{array}$ & Rarely, March-April \\
\hline Ziziania latifolia & 3persons & Half cement bag & $\begin{array}{l}\text { Half cement bag, } \\
\text { INR.200-300 }\end{array}$ & Seasonal & Market, food & April-October \\
\hline
\end{tabular}




\begin{tabular}{|c|c|c|c|c|c|c|}
\hline Scientific name & Team & Volume(Kg)/person & Rate(INR.) & No. of visit per week & Purpose & Availability \\
\hline Alpinia nigra & 3 persons & $\begin{array}{l}\text { Cement bag }(20 \times 30 \\
\text { inches })(10 \mathrm{~kg})\end{array}$ & INR.400/bag & Everyday & Market, food & Throughout the year \\
\hline $\begin{array}{l}\text { Hedychium } \\
\text { coronarium }\end{array}$ & 3 persons & $10 \mathrm{~kg}-20 \mathrm{~kg}$ & INR.400/bag & Everyday & Market, food & Throughout the year \\
\hline $\begin{array}{l}\text { Hydrilla } \\
\text { verticillata }\end{array}$ & One person & 1boatful(3x14feet) & Nil & Everyday & Fish & Throughout the year \\
\hline Ipomoea aquatica & 1person & $\begin{array}{l}\text { 1 gunny bag ( } 40 \times 60 \\
\text { inches) }\end{array}$ & INR.200/bag & Everyday & Market, food & Throughout the year \\
\hline Leersia hexandra & $\begin{array}{l}\text { Per boat- } \\
\text { one person }\end{array}$ & $\begin{array}{l}4-5 \text { bundles/ } \\
15 \mathrm{~kg} / \text { bundle }\end{array}$ & Nil & 2trip/day everyday & $\begin{array}{l}\text { Fodder, fishery, } \\
\text { piggery }\end{array}$ & Throughout the year \\
\hline $\begin{array}{l}\text { Oenanthe } \\
\text { javanica }\end{array}$ & 1person & 1gunnybag & INR.200/bag & Everyday & Market, food & Throughout the year \\
\hline $\begin{array}{l}\text { Persicaria } \\
\text { barbata }\end{array}$ & 1person & lbasket $(1 \mathrm{~kg})$ & $\begin{array}{l}\text { INR.90- } \\
100 / 500 \mathrm{~g}\end{array}$ & Everyday & Market, food & Frequently, March-April \\
\hline $\begin{array}{l}\text { Persicaria } \\
\text { sagittata }\end{array}$ & 1person & $2 \mathrm{~kg}$ & 10minute & Everyday & Market, Food & June-July \\
\hline Phragmites karka & $5-10$ team & 100-200bundles & $\begin{array}{l}\text { INR10minute/ } \\
\text { bundle }\end{array}$ & Everyday & $\begin{array}{l}\text { Household, } \\
\text { commercial }\end{array}$ & Rarely, March-April \\
\hline Ziziania latifolia & 3 persons & Half cement bag & $\begin{array}{l}\text { Halfcementbag, } \\
\text { INR.200-300 }\end{array}$ & Seasonal & Market, food & April-October \\
\hline
\end{tabular}

Species most preferred by the informants belonged to food plants relished by the communities. Analysis of the ten most preferred species collected by the villagers indicated the importance of sustainable utilization of such plants in view of conservation of Sangai. Table 5 shows the resource competition between villagers and Sangai deer for those species, which are used as food or shelter by Sangai. A voracious management planned to be developed for KLNP with specific items for management.

Table 5. Resource competition between villagers and Sangai deer

\begin{tabular}{lll}
\hline Species & $\begin{array}{l}\text { Collected by the } \\
\text { Villagers }\end{array}$ & $\begin{array}{l}\text { Importance to Brow- } \\
\text { Antlered Deer }\end{array}$ \\
\hline $\begin{array}{l}\text { Alpinia nigra } \\
\text { Hedychium } \\
\text { coronarium }\end{array}$ & Food, commodity & Food \\
$\begin{array}{l}\text { Hydrilla vercillata } \\
\text { Ipomoea aquatica }\end{array}$ & Food, commodity & Food \\
$\begin{array}{l}\text { Leersia hexandra } \\
\text { Fenanthe javanica }\end{array}$ & Food, commodity & Food, commodity \\
$\begin{array}{l}\text { Persicaria barbata } \\
\text { Persicaria }\end{array}$ & Food, commodity & Food \\
sagittata & Food & Food \\
Phragmites karka & Construction and & Shelter \\
Ziziania latifolia & Food & Food \\
\hline
\end{tabular}

However, because of various constraints in manpower rand logistic support, forest guards of the Department of Forest, Government of Manipur could not provide adequate protection to the National Park. Traditional peoples with their long associations with nature and a deep understanding of it have made significant contributions for the maintenance of many fragile ecosystems, through their traditional sustainable resource use practices and culture-based respect for nature. Over exploitation of plants from the KLNP even in the lean season is a common practice, e.g. over-matured Loklei (Hedychium coronarium) and Pullei (Alpinia nigra) rhizomes were collected and sliced or crushed into pieces and sell it in the local markets. However, after harvesting plants may grow there will be a significant effect on the lowering of the biomass in the next season [24-29]. Traditional communities are selective in collecting the economic plants from the protected areas. The anthropogenic activities prevail is to sustain livelihoods of the people as well as to enhance their overall well being through the management of economically important plant species of the park [23].

Still, there is no holistic approach for sustainable utilization of these resources as food, fodder and other purposes. As described earlier, extension of villagers inside KNLP is usually around 1 to $2 \mathrm{~km}$ into the part from the perimeter; these are as can be maintained as buffer zones. As the area reserved for KNLP is considered small, still there is no separate allocation of a buffer area. Segregation of buffer zone as espoused to other works, could contribute towards more intensive conservation approach in the core area and community-based conservation approach in the buffer zones.

Microbiological analyses for the six study sites of KLNP recorded high pollution in almost all the parts of the park. High values of Standard Plate Count (SPC) for bacteria ranging from 73,500-96,500 and microbial analysis of MPN (Most Probable Number) of coliform bacteria varied between 100 and 320/100 $\mathrm{ml}$ and faecal coliform between 95 and $200 / 100 \mathrm{ml}$. The results are in conformity with the works of the previous workers [23].

Water quality analys is of KLNP is shown in Table No. 6, in which $\mathrm{pH}$ values of the water range from 3.0 and 8.0. Lower $\mathrm{pH}$ in the main area might be due to the nutrient uptake and also due to the degradation of organic matter [23]. The degradation of Phumdis as a continuous process might be due to the acidic conditions (lower $\mathrm{pH}$ ) of the water of KLNP thereby leading to the changing pattern of the microbial population of the park because of pollution thereby increasing the faecal pollution of the lake. Due to the installation of Loktak Hydro-electric Project, water level of the lake has to be maintained high throughout the season, thereby, deterioration of Phumd icannot be controlled. In this regard, a detailed investigation is eminent. Free $\mathrm{CO}_{2}$ 
concentrations of the water of KLNP is variable at the surface (from 2-60 mg/l) and 6-70mg/l at the bottom of the lake (Table 6). In the KLNP environment the higher $\mathrm{CO}_{2}$ and lower concentrations of dissolved oxygen (DO) (Table 6) might be due to the floating mat (Phumdi) environment, in which penetration of light and exchange of gases for the process of photosynthesis impeded [23]. Most probably due to high organic load that increases microbial density. They use up available oxygen rapidly.

In the present investigation, it can be concluded that the deforestation particularly jhum cultivation, landuse and cover change might have drastically affected the water quality of the lake [30]. A comparative analysis of water quality of six different sites indicates significant levels of pollution in the densely populated sites as compare to that of less populated sites because dissolved oxygen was low and biochemical oxygen demand and other parameters including nutrient levels were higher in the densely populated sites (Table 6). High intensity of fertilizer usage in the agricultural fields and practice of fish farming contribute significantly to water quality deterioration in the northern zone [30]. Out of the thirteen parameters analyzed for the six study sites of KLNP, three study sites (Keibul, Komlakhong and Nongmaikhong) recorded higher dissolve oxygen, BOD above the WHO standard limit because of the higher pollutants with higher population (Table 6). The report is in conformity with tha tof Laishram and Dey [31].

Table 6. Variation of Water quality at six study sites of KLNP

\begin{tabular}{|c|c|c|c|c|c|c|}
\hline Parameters & Sargam & Keibul & Nongmaikhong & Khordak & Komlakhong & Kumbi \\
\hline Population & 848 & 3100 & 990 & 832 & 3539 & 399 \\
\hline Temperature $\left({ }^{0} \mathrm{C}\right)$ & 26 & 27 & 27.5 & 28 & 27.8 & 27.0 \\
\hline $\mathrm{pH}$ & 6.8 & 7.50 & 7.31 & 7.1 & 7.23 & 7.56 \\
\hline BOD (mg/l) & 1.1 & 4.1 & 4.5 & 1.5 & 4.9 & 1.8 \\
\hline Free $\mathrm{CO}_{2}(\mathrm{mg} / \mathrm{l})$ & 10 & 28 & 15 & 21 & 31 & 19 \\
\hline Dissolved $\mathrm{O}_{2}(\mathrm{mg} / \mathrm{l})$ & 0.82 & 5.20 & 5.12 & 4.4 & 6.25 & 4.3 \\
\hline Hardness (mg/l) & 25 & 37 & 29 & 44 & 39 & 34.1 \\
\hline SPC (Standard Plate Count) (per ml) & 73,500 & 96,500 & 90,000 & 70,500 & 94,400 & 71,200 \\
\hline MPN (Most probable number) of Coliform Bacteria (per 100ml) & 100 & 320 & 300 & 305 & 300 & 220 \\
\hline Faecal Coliform (Per100ml) & 95 & 200 & 196 & 190 & 180 & 170 \\
\hline Chlorides (mg/l) & 5.2 & 8.3 & 12.1 & 10.2 & 9.5 & 7.3 \\
\hline Alkalinity (mg/l) & 50 & 55 & 40 & 61.5 & 45 & 70 \\
\hline Calcium (mg/l) & 14 & 22 & 13 & 25 & 18 & 20 \\
\hline Magnesium (mg/l) & 14 & 25 & 15 & 25 & 21 & 19 \\
\hline
\end{tabular}

\section{Conclusions}

Nambul and Nambol rivers directly pooled to Loktak Lake, so southern zone is polluted due to flow of the pollutants finally in these zones and their accumulation due to poor flushing. The lake dwellers, which are responsible source of threat to the lake ecosystem, need proper attention and monitoring. People participation can be practiced as per demand of the prevailing situation so that it leads to self management [30].

Traditional communities have their own preference throughout the season among the plants collected from the park. Many of the highly preferred plants collected by them are the natural food of the Sangai deer. Overharvesting of these plants may cause serious shortage of food to the deer thus endangering their existence. At the same time, the age old tradition of traditional communities needs to be upheld in conserving and maintaining protected areas. Considering these various aspects, highlighting the importance of community based approach in reduction of overharvesting becomes relevant. So it is true that the survival of the communities is the crisis of the biodiversity, which is intimately linked with the disappearance of ecological diversity and ultimately the struggle for the preservation of biodiversity [32]. So the lake dwellers of Loktak Lake are responsible for the loss of wild edible plants and it will seriously deplete the resource base on which the evolutionary processes can operate in the future [33].

\section{References}

[1] A.White, A.Molnar and A.Khare, Whoowns, who conserves and Why It Matters. ForestTrends, Washington DC,2004.

[2] D.Brockington and J.Igoe, Eviction for Conservation: A Global Overview. Conservation and Society, 4(3):424470,2006 .

[3] A.Crowder and D.S.Painter,Submerged Macrophytes in Lake Ontario: Current knowledge, Importance,Threats to stability, and Needed studies. Canadian Journal of Fisheries and Aquatic Sciences,48(8):1539-1545,10.1139/f91-182,1991.

[4] M.H.Devi, P.K.Singh, and M.D.Choudhury, Income generating plants of Keibul Lamjao National Park, LoktakLake, Manipur and man-animal conflicts. Pleione, 8(1):30-36, 2014

[5] A.D.Livingston and H.Livingston, The Wordsworth Guide to Edible Plants \& Animals. Wordsworth Editions Ltd.Cumberl and Hous,CribStreet,Ware, Hertfordshire, pp.192,1996.

[6] T.Teklehaymanot and M.Giday, Ethnobotanical study of wild edible plants of Kara and Kwegosemi-pastoralist people in Lower Omo River Valley, Debub Omo Zone, SNNPR, Ethiopia. Journal of Ethnobiology and Ethnomedicine, 6:23,2010. 
[7] G.Pelto,P.Pelto and E.Messer, Research methods in nutritional anthropology. United Nations University Press, Tokyo, Japan,1989.

[8] R.P.Mukherjee, Report on the brow-antlered deer of Manipur. Mimeo,6p,1975.

[9] W.J.McShea, P.Leimgruber, M.Aung, S.L.Monfort and C.Wemmer, Range collapse of a tropical Cervid(Cervuseldi) and the extent of remaining habitat in central Myanmar. Animal Conservation, 2:173-183,1999.

[10] IUCN, Guidelines for Protected Area Management Categories. CNPPA with the assistance of WCMC, IUCNG land, Switzerland and Cambridge,UK,1994.

[11] H.T.Singh and R.K.S.Singh, Ramsar sites of India Loktak Lake Manipur, Work Wide Fund for Nature, India,23p,1994.

[12] E.P.Gee, The brow-antlered deer of Manipur. Oryx, 6(2):103115,1961 .

[13] J.L.Lockwood, M.F.Hoopes and M.P.Marchestti, Invasive Ecology. Blackwell Publishing,UK,2007.

[14] I.Stiers,J.Njambuya and L.Triest, Competitive abilities of invasive Lagarosiphon major and native Ceratophyllum demersunin monoculture and mixed cultures in relation to experimental sediments dredging. Aquatic Botany, 95:161166,2011 .

[15] R.N.Ntumngia,Uncovering farmers'ethnobotanical knowledge: A methodology for assessing farmers' perceptions of Cassava varieties, African Crop Science Conference. African Crop Science Society,467-473p,2009.

[16] M.Hoft,S.K.Barik and A.M.Lykke, Quantitative Ethnobotany: Applications of multivariate and statistical analyses in ethnobotany.UNESCO, Paris,1999.

[17] J.Kemeny, Mathematics without numbers. Daedalus, 88:577591,1959 .

[18] http://www.votefair.org/calculation_details_popularity.html

[19] N.P.Singh, A.S.Chauhan, M.S.Mondal, Flora of Manipur (Ranunculaceae-Asteraceae) Vol 1, Botanical Survey of India, Printed at Roman Printers Pvt.Ltd.Calcutta,2000.

[20] www.ipni.org

[21] www.theplantlist.org

[22] A.Jain, S.C.Rai, J.Pal and E.Sharma, Hydrology and nutrient dynamics of a sacred lake in Sikkim Himalaya. Hydrobiologia,416: 12-22,1999.
[23] C.L.Trisal and T.Manihar, Loktak The Atlas of Loktak, Wetlands International and Loktak Development Authority, 2004.

[24] J.C.Kimbel and S.R.Carpenter, Effects of mechanical harvesting on Myriophyllum spicatum L. Regrowth and carbohydrate allocation in roots and shoots. Aquatic.Bot.,11,121-127,1981.

[25] S.Engel, Ecological impacts of harvesting macrophytes in Halverson lake,Wisconsin,USA. J.Aquat.Plant Manage,28:4145,1990 .

[26] T.R.McClanahan,Harvesting in a nuncertain world-impact of resource competition on harvesting dynamics. Ecol.Model., 80:21-26,1995.

[27] A.Dall'Armellina, A.Gajardo, C.Bezic, E.Luna, A.Britto and V.Dall'Armellina, Mechanical aquatic weed management in the lower valley of the RioNegro, Argentina. Hydrobiologia,340:225-228,1996.

[28] M.S.vandenBerg, H.Coops, M.L.Meijer, M.Scheffer, J.Simons, Clear water associated with a dense Chara vegetation in the shallow and turbid Lake Veluwemeer, the Netherlands, In: Jeppesen,E.,Sondergaard,Ma.,Sondrgaard,Mo.Kristoffersen,K. (Eds.), Structuring Role of Submerged Macrophytes in Lakes. Springer-Verlag, NewYork, pp.339-352,1998.

[29] E.H.vanNes, M.Scheffer, S.vandengBerg and H.Coops, Aquatic macrophytes: restore, eradicateor is there a compromise. Aquatic Botany,72:387-403,2002.

[30] S.C.Rai and A.Raleng, Ecological Studies of Wetland Ecosystem in Manipur Valley from Management perspectives. In Ecosystems Biodiversity, Oscar Grillo (Ed.), In Tech, Available from: www.intechopen.com, Chapter-11:233-248, 2011.

[31] J.Laishram and M.Dey, Water Quality status of Loktak Lake, Manipur, Northeast India and Need for conservation measures: A study on five selected villages, International Journal of Scientific and Research Publication, 4(6): 1-6,2014.

[32] V.Shiva, P.Anderson, H.Schucking, A.Gray, L.Lohmann and D.Cooper, Biodiversity Social \& Ecological Perspectives. World Rainforest Movement, Penang, Malaysia,123p,1991.

[33] N.Myers, Tropical Deforestation and a Mega-Extinction Spasmin SouléM. Edition: Conservation Biology-The Science of Scarcity and Diversity, Sinauer Associates Massachusetts, 1986. 